\title{
Spatiotemporal pattern of forest degradation and loss of ecosystem function associated with Rohingya influx: a geospatial approach
}

\author{
Mohammad Emran HASAN ${ }^{1}$, Li Zhang ${ }^{2}$, Ashraf Dewan ${ }^{3}$, and Riffat Mahmood ${ }^{1}$ \\ ${ }^{1}$ Chinese Academy of Sciences \\ ${ }^{2}$ Aerospace Information Research Institute, Chinese Academy of Sciences \\ ${ }^{3}$ Curtin University
}

June 28, 2020

\begin{abstract}
Violence in Rakhine, Myanmar forcibly displaced nearly one million Rohingya who took refuge in Cox's Bazar-Teknaf peninsula of Bangladesh. Initially, nearly 2,000 ha of forested lands had to be cleared to accommodate them in an area, that is ecologically very sensitive. Fuelwood collection and illegal logging have become widespread since their arrival, causing severe environmental degradation, including loss of a vast amount of forest cover. To devise conservation strategies of a highly sensitive ecosystem, it is imperative to understand the degree of forest cover deterioration and associated impacts related to Rohingya emigration. This study employed satellite images to monitor and model spatiotemporal pattern of forest cover degradation, and loss of ecosystem function in the peninsula. Supervised classification method was used to derive multidate land use/cover data which was then utilized to monitor spatiotemporal pattern of forest cover change from 2017-2019. Dynamic modelling was performed to predict changes in the forest covers using markov cellular automata. Analysis revealed that 3,130 ha of different forested covers were transformed into either refugee camps or degraded forest cover between 2017 and 2019. Prediction showed that around 5,115 ha of forest may experience loss from 2019-2027. Furthermore, above ground biomass and carbon stock estimation indicated a consistent loss, which is likely to swell if present rate of deforestation continues. The findings of this work have considerable implications in developing conservation decisions, priority interventions and public policies to save an ecologically sensitive area.
\end{abstract}

\section{Introduction}

Globally, forcibly displaced population reached remarkably high from $43.3 \mathrm{~m}$ in 2009 to $70.8 \mathrm{~m}$ in 2018 , largely because of persecution, conflict, violence or human rights violations (UNHCR, 2019). Presence of displaced people may introduce a range of effects to the host environment of which deforestation, land degradation and impacts on water supply and quality are noteworthy (Black, 1994). However, severe pressure on local environment causes forest cover to deplete substantially (Hagenlocher et al. 2012; Birendra and Nagata, 2006) due to enhanced competition for natural resources between displaced communities and local population (Chambers, 1986). Furthermore, clearing of forest cover evidently reduces ecosystem functions and services (Foley et al. 2007). For instance, biomass and carbon stock depletion in relation to deforestation caused by increased human activities can accelerate climatic change at regional and local scales (Panja, 2020; Bonan, 2008; Malhi et al. 2002).

Following severe violence in Myanmar's Rakhine State in 2017, nearly a million forcibly displaced Rohingya population (a minority ethnic group) took refuge in Cox's Bazar- Teknaf peninsula of Bangladesh (UNHCR, 2017), which is believed to be the largest refugee camp in the world at present (Kolstad, 2018; IOM, 2017). Although Rohingya issue dated back in 1942 (Human Rights Watch, 2000), their influx is multiplied since August 2017 (UNOCHA, 2018). A total of 932,940 Rohingya are now being hosted in 48 temporary camps 
which are located either within the reserve forests or in a close proximity to forested lands (UNDP Bangladesh and UN WOMEN Bangladesh, 2018). Since Cox's Bazar- Teknaf peninsula is an ecologically critical area (ECA) (DOE, 2015), hosting such a big number of refugee population is not only a significant threat to the environment (Hassan et al. 2018; Rahman, 2017) but also has implication for local and regional security (Bashar, 2018; Rahman, 2010). Forest clearance for building camps and ensuring livelihood activities (Lynch, 2002; Rashid et al. 2020), especially within $15 \mathrm{~km}$ of the camps (Sato et al., 2000), are two major issues that the peninsula is currently facing. Although the Rohingya communities are supported by different organizations, these supports do not guarantee cash flow, hence they have no or limited livelihood options (IOM and FAO, 2017). Therefore, they depend on available forest resources to maintain their livelihoods (Wilson, 1994; GTZ, 1994), which is posing a significant threat to forest resources (Ghimere, 1996). Besides, cooking requires fuelwood (IOM and FAO, 2017) which is being met up through harvesting from locally available natural and community forests. Since refugees use natural resources in a more unsustainable way than local communities (Black and Sessay, 1998), long- term impacts on natural resources could be irreversible.

Various impacts associated with forced displacement on host environment are noted in a number of studies (see Hagenlocher et al. 2012; Black, 1994), however the extent of ecosystem degradation depends on factors like destination country's capacity (Hugo, 1996), degree of disturbance to forests (Shukla et al. 2011) and institutional arrangement (Black and Sessay, 1998). Since Bangladesh is densely populated and have limited natural resources, particularly forested lands, sheltering nearly one million Rohingya over the peninsula resulted in a variety of impacts, including severe depletion of forest covers (Ahmed et al. 2019). As best management practice requires information about spatiotemporal pattern of the past, present and future scenarios of a geographic phenomenon (e.g., forest ecosystem), monitoring and predicting forest extent in the peninsula with satellite data could be of great value (Bjorgo, 2000a; Lodhi et al. 1998). Although geospatial data are valuable source of information for crisis and disaster management, relatively little is done in elucidating degradation of natural forest and related ecosystem function in response to a sudden humanitarian crisis such as Rohingya. This work aims to fill this void. Despite a couple of works attempted to estimate forest loss (Ahmed et al. 2019; Hassan et al., 2018), they are however limited in data and scope. Notably, they are unable to show factors accountable for forest degradation, prediction of forest degradation (assuming business- as- usual scenario), and most importantly, loss of ecosystem function over space and time. Planning and efficient management of meagre natural resources requires up- to- date data, therefore, availability of existing forest resources and potential loss in relation to refugee migration is expected to provide crucial information to managers and policymakers (Morales-Hidalgo, 2015; Romijn et al., 2015; Bouchardy, 1995; Bjørgo, 1999). This work, thus, attempts to answer two research questions: (i) what is the extent of forest degradation in environmentally sensitive Cox's Bazar- Teknaf peninsula in response to Rohingya influx; and (ii) what is (would) be the degree of ecosystem function loss, at present and in the future, under multiple stressors and stimulus, if Rohingya issue persists.

\section{Materials and methods}

\subsection{Description of the study area}

The peninsula is located in Cox's Bazar, a southeastern most district of Bangladesh. As this study focuses on the impact of Rohingya on forest degradation and ecosystem function loss, it considers administrative boundaries of Bangladesh Forest Department (BFD). In Cox's Bazar district, there are two forest divisions, i.e., north and south, however refugee camps are mostly built in South division (BFD GIS Database). Based on influx of Rohingya and their catchment area, this study takes 23 beats into account (beat is the smallest forest administrative unit, defined by BFD) of south forest division. To understand future condition of forest cover, we further consider some portion of the Naikhongchari beat of Bandarban forest division defined by IOM and FAO (2017). The use of beat may be beneficial to investigate future impact of refugee in every direction from existing camps. There are three sub-districts (upazilas) and 24 beats within the study area (Fig. 1). Geographically, it is located between $92^{\circ} 17^{\prime} \mathrm{E}, 20^{\circ} 50^{\prime} \mathrm{N}$ and $92^{\circ} 12^{\prime} \mathrm{E}, 21^{\circ} 19^{\prime} \mathrm{N}$, and covers an area of 41,162 ha. 
Irrespective of administrative boundaries, defined by BFD and Bangladesh Bureau of Statistics (BBS), environmentally, the study area situated in a very sensitive ecosystem. It includes Teknaf Wildlife Sanctuary (TWS) (GoB, 2009; BFD, 2014) formerly known as the Teknaf Game Reserve (TGR) (Alam et al. 2012). Besides, it has proposed Inani National Park (Nishorgo, 2019), which is a reserve forest (Belal, 2013; Rahman, 2011). The area of the TWS is 11,615 ha (Green, 1987; Nishorgo, 2019, Moslehuddin et al., 2018), covering $25 \%$ of the study area, and situated in close proximity to Rohingya camps. Inani Reserve Forest has an area of 15,500 ha, covering $33 \%$ of our study area. The other reserve forest comprises an area of 6,365 ha, which covers $13.5 \%$ of the study area. Therefore, $71 \%$ of the study area includes a critical ecosystem and the rest $(29 \%)$ is no- forested land, occupied by human settlements and agricultural lands. As a tropical semi- evergreen forest, the area is home to a wide variety of flora and fauna, including 55 mammals, around 280 birds, 56 reptiles, 13 amphibians and 290 plant species (Khan, 2008; Nishorgo, 2019). The study area also serves as a key habitat to critically endangered flagship species of Asian Elephants (Elephus Maximus ) (Khan, 2015). It is characterized by hot and humid climatic conditions, and therefore, conducive for a range of biodiversity (Butler, 2012). Prior to recent influx, Rohingya communities are living in two camps since 1942 (Fig. 1) (Human Rights Watch, 2000) within the study area. After 25 th of August 2017, with a massive influx, they are now located in 48 camps. The density of Rohingya population is shown in Fig. 1.

\subsection{Data acquisition and preparation}

This study considers both spatial and non- spatial data and they have been acquired from a variety of sources (Table 1). Satellite data includes Sentinel 2A, RapidEye, World View-2, multi- date UAV and a digital elevation model from Shuttle Radar Topographic Missing (SRTM). Sentinel images represent winter season and pre- and post- influx of Rohingya situations. Vector data includes administrative boundary and location of camps, obtained from Survey of Bangladesh (SoB), BFD and UNHCR. In addition, human trails are derived from the UAVs and Google Earth imageries and population data of each camp was obtained from FCN- UNHCR and NPM- IOM. In addition, a field survey was conducted in February 2018 to understand state of the environmental condition. Observational technique along with photographic method was accepted, during the field works, to support satellite- based evaluation of forest function loss in the study area.

Sentinel 2A imageries are first geometrically corrected and a root mean square error (RMSE) of $<1$ pixel is accepted. Atmospheric correction is then carried out with SEN2COR toolkit to convert Top of Atmosphere (TOA) value to surface reflectance (Cleverset et al., 2017; Quintano et al., 2018). A Universal Transverse Mercator (UTM) system with $46 \mathrm{~N}$ is used to project spatial datasets and then clipped to the study area boundary.

\subsection{Image classification and accuracy assessment}

A modified version of the Anderson level 1 land use and land cover (hereinafter, LULC) classification scheme (Anderson et al., 1976) is used to classify Sentinel data into discrete LULC categories (Table 2). A hybrid approach, comprising unsupervised and supervised techniques, is employed (Bauer et al., 1994). First of all, an Iterative Self- Organizing Data Analysis (ISODATA) algorithm is used to derive signatures from multitemporal Sentinel data, pertaining to the study area. The signatures were then evaluated using histogram and transform divergence (TD) techniques to ensure normality (Yuan et al., 2005). The TD value of [?] 1900 is accepted in this work. Besides, reference data (e.g., RapidEye, World View- 2 and Google Earth Images) for each year is considered, side- by- side, in an image processing system to determine the usefulness of individual signatures. This process helps isolating signatures that are suitable for classifying images. A maximum likelihood routine is subsequently applied to derive distinct LULC categories (Bolstad \& Lillesand, 1991). Since the study area has diverse land covers, misclassification of pixels is noticed between shrubs and agriculture, mixed forest, and canopy trees and homestead vegetation cover. To subdue issues with misclassification, post- classification refinement is carried out to recode mixed pixels into correct LULC categories (Harris \& Ventura, 1995). Finally, three maps of the study area are obtained, representing LULC data of 2017, 2018 and 2019.

To evaluate classification accuracy, 100 points for each LULC classes are derived from high resolution images, 
noted above (Table 1), with a stratified random sampling technique. Using reference data and classified images, an error matrix is then prepared from which four accuracy metrices (e.g., overall, producers, user's accuracies and kappa statistics) are computed.

\subsection{LULC change detection and analysis of spatial trend}

A post- classification change detection technique is used to determine changes in LULC categories between 2017 and 2019. This process resulted in three change detection maps; (i) 2017- 2018; (ii) 2018- 2019; and (iii) 2017-2019. These operation helps defining changes in LULC which subsequently aid in assessing forest degradation, caused by resettlement of Rohingya populations. Earlier (e.g., 2017) and later (e.g., 2018) thematic maps are compared, on a pixel- by- pixel basis, and transformation of LULC categories is defined to compute changes from a specific land class to other classes (e.g., shrubs to Rohingya camps). The spatial trend is then analyzed, based on the pattern of change between earlier and later periods. Third order polynomial equation is used to analyze the spatial change pattern. The resulting trend surfaces aid understanding the direction of LULC change.

\subsection{Prediction of LULC change}

Based on the classified maps, this study also attempts to predict LULC for 2023 and 2027. Three steps are involved in the prediction process. They are estimation of transition probabilities, creation of transition suitability maps and finally predicting LULC. A combination of Markov chain with cellular automata (CA) method is employed as former technique is unable to provide spatial dimension of a phenomenon. To simulate future land covers, actual data of 2017- 2018 are used to predict 2019 LULC which is then compared with observed data of 2019 to check the effectiveness of model.

Transition probability matrix is derived through markov module as a first step. LULC thematic maps of different periods are inputted to estimate transition probabilities (Pijanowski et al., 2002). A suitability map for each of LULC class defines transformation suitability of a certain class from all other categories (Halmy et al., 2015). Stressor and stimulus parameters are, therefore, required to develop suitability map to account dynamic aspect of land cover change. In this work, forest degradation is based on both stressor and stimulus parameters. Stimulus variable includes number of Rohingya population, stressor parameter comprises high elevation, and constraint is defined by highly protected areas. The stressor, constraint and stimulus variables are determined on the basis of previous studies (e.g., IOM and FAO, 2017; IUCN Bangladesh, 2018), 2018 field works and local knowledge of the sites (Table 3). Since not all LULC classes are subject to change rapidly, six dynamic (Table 3) and one constraint variables are included to isolate suitable locations or forest patches that could be degraded under the influence of refugee occupancy.

As degradation of forest is accelerated by fuelwood collection and illegal logging by the Rohingya communities, distribution of Rohingya population is a key factor for a suitability map. Apart from population variable, four distance variables (Table 3) are also considered. Due to the fact that the Rohingya can travel up to $16 \mathrm{~km}$ (IOM and FAO, 2017), and on average, $7 \mathrm{~km}$ to collect forest resources, a 7 - $\mathrm{km}$ buffer is constructed using center of each refugee camps. These buffers are then intersected with population distribution to identify number of people that can conceivably influence forest degradation. In other words, if a forest area is within a distance of $7-\mathrm{km}$ buffer of three camps (C1, C2 and C3) and these camps contain 100, 200 and 150 people, then a particular forest cover has a total of 450 humans. These populations are considered as potentially degraders. The results are subsequently aggregated to a 100x100 m grid based on which a ranking is performed. This helps determining forest covers subject to degradation due to existence of the Rohingya communities. The higher the population in each grid, the greater the likelihood of a forest to be degraded. In the creation of forest degradation suitability maps, maximum weighting (0.5) is assigned to population field whereas other parameters receive rest of the weights (0.5), using a scale of 0-1. A weighted linear combination method is then employed to develop transition suitability maps.

The transition probability or transition suitability maps of 2017- 2019 are considered, wherein 2019 LULC is used as base. Since CA Markov provides spatial distribution of LULC change, area of each class to be changed to other classes are determined by transition potential or transition suitable maps (Halmy et al., 
2015). These transition areas are divided by the number of time periods in the simulation $(1,4$ and 8 in this case). This operation provided areas to be converted to another LULC class. The CA Markov with these principles results predicted LULC data which are then assessed for accuracy by considering kappa index of agreement and disagreement. LULC prediction for the year of 2023 and 2027 are conducted, based on actual data of 2019 (Pontius and Millones 2011).

\subsection{Estimating above ground biomass and carbon stock}

Above ground biomass (AGB) is an important function that a forested land offer, and plays an important role in the study of carbon cycle and climate change ( $\mathrm{Li}$ et al. 2020). This indicator can be highly useful to discern quality of an ecosystem in terms of habitat condition and biodiversity hotspot (Zolkos et al. 2013). AGB and carbon stock in this work are determined, both in space and time, to understand stresses that Cox's Bazar-Teknaf forest ecosystem is experiencing due to massive influx of Rohingya. Since the study area is inaccessible as being hilly and this study is constrained by logistics, biomass data for selected forest classes are obtained from an earlier inventory (IOM and FAO, 2017). In total, 57 subplots within 15 major plots, covering a total sample area of 6.48 ha, were used to collect AGB parameters, e.g., diameter at breast height (DBH), and height for trees and saplings. Five major LULC were considered by the inventory of IOM and FAO (2017). It is important to note that four major forest covers such as shrubs, mixed forest, planted trees and canopy forest are considered in this work, due to their greatest role in regulating ecosystem function (Li et al. 2020; Panja, 2020). A 100x100 grid is used to estimate area of each four categories which is then multiplied with AGB (ha) values of the respective forest classes (viz., 2, 17,003, 2 and 180,038 $\mathrm{kgs}$ for shrubs, mixed forest, planted forest and canopy forest). The values are subsequently summed to get total biomass in kilogram $(\mathrm{kg})$ per grid. To obtain total carbon (in $\mathrm{kg} / \mathrm{grid}$ ), derived biomass values are divided by two (2). A maximum of 180,038 $\mathrm{kg}$ AGB or 90,019 $\mathrm{kg}$ carbon per grid is possible, if a grid contains $100 \%$ canopy forest. In contrast, $0 \mathrm{~kg}$ of biomass and carbon/grid is possible, if a grid has no forest, i.e., camps.

\section{Results}

\subsection{Spatiotemporal distribution of $L U L C$}

Fig. $2(\mathrm{a}-\mathrm{c})$ illustrates LULC categories, and they are useful to identify state of forest cover in the study area. Inspection of individual land use/cover categories, derived from Sentinel images, revealed pre- and post- influx situations. For example, loss of forested land was largely distributed along the Inani National Park and TWS before influx of Rohingya (Fig. 2a), however, the distribution of degraded forest, defined by poor vegetation health, increased substantially in the subsequent years (e.g., 2018 and 2019) (Fig. 2b-c).

Temporal information of LULC data over the study area showed that four land covers, viz., homestead vegetation, shrubs, mixed and canopy forests, experienced a significant decline from 2017 to 2019, and a manifold increase in two human- dominated land covers, viz., camps and degraded forest (Table 4). For instance, mixed forest cover declined from 10,593 ha in 2017 to 9,645 ha (2018) and 9,303 ha (2019), respectively. In contrast, Rohingya camps increased from 78 ha (2017) to 1,968 ha in 2019. Likewise, degraded forest increased from 1,862 ha (2017) to 3,792 ha in 2019. Further, field works demonstrated that areas nearby the camps are completely cleared, and therefore, topsoil is severely exposed (Field Survey, 2018) (Fig. 3a). Moreover, due to high demand of fuelwood, soil is dugged to uncover and pull out the plant's remnants, especially the root of trees (Fig. 3b).

The gains and losses are analyzed, which demonstrated that agricultural land decreased to about 267 ha in 2017- 2018 and 190 ha in 2018- 2019. The maximum reduction is observed in two land covers categories, shrubs and mixed forest. During 2017-2019, shrubs reduced to about 1,495 ha and mixed forest experienced a decrease of 1,289 ha. Homestead vegetation, planted young forest and canopy forest covers also reduced (208 ha, 160 ha and 184 ha, respectively) but not in the same magnitude of shrubs and mixed forest land covers. On the other hand, degraded forest had a maximum increase of 1,929 ha followed by Rohingya camps (1,889 ha) during 2017-2019. Because forest covers such as shrubs, mixed forest, plantation forest and canopy forest are vital components of a forest ecosystem, loss of these covers is indicative of the deterioration of the ecosystem. Hence, this finding is crucial to understand loss of individual forest covers as well as specific 
decline of the respective ecosystem functions.

LULC changes between years is presented in Fig. 4, which shows changes of one land cover to another. It also shows spatial trend map of 2017-2019, suggesting that the impact of Rohingya on forested lands was higher in and around the refugee camps than locations further away. This clearly features the effect of Rohingya on the forest covers in the peninsula.

A 'from- to' analysis with a GIS function was performed (Table 5), which shows contribution of major LULC categories to camps and degraded vegetation class during 2017 to 2019. Agriculture, homestead vegetation, shrubs, mixed forest, plantation forest and canopy forest land covers contributed to the establishment of refugee camps between 2017 and 2018, when massive influx started for the first time in August 2017, however shrubs, mixed forest, plantation forest and canopy forest covers contribution reduced substantially during 2018- 2019. This possibly reflects host country's measures to protect important forested lands in the later period. On the other hand, shrubs and mixed forest contributed largest to degraded forest cover in 20172018 relative to other categories. During 2018- 2019, four important forest covers (viz., shrubs, mixed, plantation forest and canopy forest) experienced greatest degradation (Table 5). For instance, loss of shrubs cover was 701 ha (i.e., converted to Rohingya camps and degraded forest covers) in 2017- 2018 which increased to a loss of 905 ha during 2018-2019, suggesting amplified pressure of Rohingya refugee on the forest systems of the peninsula.

The analysis of forest degradation as a function of population pressure was conducted using total population of the camps and six land use/covers variables (e.g., canopy forest, mixed forest, shrubs, planted trees, degraded forest and camps) and the result is presented in Table 6 . The relationship indicates that an increase of population resulted in a decrease of forested lands and positively related with Rohingya camps and degraded forest covers. In other words, degraded forest cover and camps substantially increases with an increase of human populations in the study area (Table 6). However, $\mathrm{p}-$ value of the correlation matrix was statistically insignificant, ranging from $0.022-0.361$ at the $95 \%$ confidence interval.

The accuracy assessment showed that overall accuracy of 2017, 2018 and 2019 LULC maps is $86.85 \%, 89.12 \%$ and $91.45 \%$ with corresponding kappa of $0.86 \%, 0.88 \%$ and $0.91 \%$, respectively. This signifies that derived LULC information have an acceptable level of accuracy (Abdullah et al. 2019; Zhang et al. 2013). Hence, these maps are inputted to predict spatiotemporal changes in future LULC by assuming business- as- usual scenario, i.e., if the Rohingya communities continues to live in current locations.

\subsection{Prediction of forest cover change}

Based on population density, physiography, accessibility and other factors (Table 3) along with transition probabilities and spatial trend, this study predicts forest cover scenario for 2023 and 2027. Fig. 5 shows observed versus simulated LULC categories of 2019. The result clearly demonstrates performance of MarkovCA approach in simulating LULC. The accuracy of the prediction showed overall accuracy and kappa of $86.21 \%$ and $0.85 \%$, suggesting a good performance of the model. However, poor simulation was achieved for landcover of mixed forest and degraded forest categories whilst best agreement was obtained for agriculture, urban, homestead vegetation categories.

Spatial pattern of land use/covers during 2023 and 2027 is shown in Fig. 6, which indicated that the distribution of degraded forest would be widespread, if Rohingya camps exist in the peninsula at the expanse of dominant land covers (e.g., shrubs, mixed forest, plantation forest and canopy forest). Specifically, shrubs land cover is expected to decline from 7,306 ha in 2019 to 5,800 and 4,871 ha in 2023 and 2027. Other land covers such as mixed forest, planted trees and canopy forest would reduce significantly as well (Table 7). Conversely, a substantial increase in degraded forest is highly likely during two years (e.g., 2023 and 2027) though a subtle increase is seen in agriculture and camp land covers (Table 7).

Forest degradation, as a function of fuelwood collection, illegal logging and other activities, was determined based on predicted LULC of 2023 and 2027. The analysis revealed that loss of forest cover would increase dramatically, if present rate of anthropogenic activities continues in the study area. Since addition of refugee 
is not expected due to host country's repeated denial, it is seen that shrubs, mixed forest, plantation forest and canopy forest would experience massive reduction of which loss of shrubs and mixed forest could be substantial (Table 8).

\subsection{Changes in biomass and carbon stock}

The spatial pattern of AGB revealed that it declined significantly due to establishment of camps to accommodate Rohingya refugee between 2017 and 2019. Fig. 7 shows that AGB decreased over space and their distribution could decline severely in the future. At temporal scale, mixed forest experienced a severe loss in biomass followed by canopy forest cover (Table 9). Since these categories play an important role in ecosystem functioning, their influence on the loss of AGB is noteworthy than shrubs and plantation forest (young trees) landcovers. It is also observed that 27,600 tons of carbon may have released to the atmosphere between 2017 and 2019 which may increase to about 71,920 tons, if deforestation continues at the current rate.

\section{Discussion}

Protection, conservation and sustainable management of forest resources are often challenging (Siry et al., 2003), especially for a country like Bangladesh. The forest resources of the country are already in a critical state because of a number of reasons, including high dependency of a large number of marginalized people for their livelihood (Moslehuddin et al., 2018; Byron and Arnold 1999). Supporting additional people to take refuge, as a result of violence in a neighboring country, seems to have aggravated current deforestation rate (Alam et al., 2014), particularly in an environmentally fragile ecosystem zone.

Close inspection of LULC maps (Fig. 2a) indicated the distribution of degraded forests in the study area but its extent was low, prior to influx. Although forest resources in the peninsula are primary source of livelihoods for local people (Tani and Rahman, 2018), influx of Rohingya intensified process of degradation that led to severe deforestation (Fig. $2 \mathrm{~b}-\mathrm{c}$ ). Loss of forest continued since then as depicted by Fig. 2 (b-c), suggesting a loss of 1600- 2200 ha in 2018 and 3200 ha in 2019. These findings are in accord with previous works (Rashid et al. 2020; Ahmed et al. 2019; Hassan et al. 2018) despite there are differences in terms of data and methods. Figure 2 (a-c) also illustrated Rohingya makeshift camps and increasing number of deforested and degraded vegetation patches, especially in close proximity to camps. A similar observation is made in Pakistan (Lodhi et al. 1998), Malawi (Babu and Hassan, 1995), Sudan (Hagenlocher et al. 2012) and Nepal (Birendra and Nagata, 2006) that deforestation increases substantially in the event of a sudden humanitarian crisis like Rohingya. Further, it is important to note that greater increase of fuelwood collection by the Rohingya communities resulted not only in clearing of forest in around the camps but also exposing top soil in the surrounding environments which can be highly detrimental. Field works as well as a previous work (Moslehudding et al., 2018) support this observation that top soil is being exposed due to pulling of remnant of trees, and such practice is albeit unhealthy for nutrient cycle of the forested ecosystem (Chen and Li, 2003).

As illegal logging and fuelwood collection are two important activities by the Rohingya communities at present, the extent of forest cover degradation is increasing over time (Table 5, Fig. 4). This type of deterioration is affecting biomass and carbon stock of the area (Table 9) which could enhance global warming (Panja, 2020). Because of forest clearance, for instance, land surface temperature (LST) of the study area increased significantly from pre- to post- influx (Rashid et al. 2020), a very influential factor that affects local climate variability (Wang et al. 2012). As release of carbon to the atmosphere could expedite global warming, additional loss of forest cover potentially can lead to change in regional climatic system (Bonan, 2008).

Since mixed forest, and canopy forest play an important role in ecosystem functioning, particularly in the study area, their influence on the loss of AGB is noteworthy than shrubs and planted young tree covers. It is also observed that 27,600 tons of carbon may have released to the atmosphere between 2017 and 2019 which may increase to about 71,920 tons in the future as showed by prediction. In addition, fragmentation of forest patches due to intensified pressure on resources can have profound impact on wildlife habitat. For example, there were two active elephant corridors within the study area, including multiple routes for their movement, 
prior to Rohingya influx (Motaleb and Ahmed, 2016). Widespread fragmentation of forest covers however reduced the extent of their habitat, causing restricted movement of the Asian elephant (Eliphus Maximus ) between adjacent habitats of 'Teknaf- Shilkhali- Whykheong- Inani- Ukhia- Ghundhum- Myanmar' and 'Dhoapalong- Himchari- Panerchara- Rajarkul- Naikhongchari' (Motaleb and Ahmed, 2016). As a result, thirty - eight elephants were trapped inside Cox's Bazar- Teknaf peninsula (National Geographic, 2018), often leading to human- elephant conflicts (UNHCR \& IUCN Bangladesh, 2018). Evidence suggests that human- elephant conflict increased to a greater number in recent times that caused killing of 13 people since August 2017 (McVeigh and Peri, 2018; UNHCR \& IUCN Bangladesh, 2018). Further, an increase of fuelwood consumption decreases fodder for elephant species, which is an utmost sign of deterioration of overall ecosystem health. Furthermore, unwise harvesting of forest biomass can jeopardize human wellbeing and ecological sustainability (Vogt et al. 2007 cited in Panja, 2020).

Based on population, physiography, accessibility and other factors (Table 3), this study predicted forest cover scenario for 2023 and 2027 (Fig. 4, Table 7) which revealed that, if current deforestation rate continues and no more Rohingya population is added further, the extent of degraded forest could increase to 3080 ha and 5120 ha, compare to 2019. This can enhance deterioration of ecosystem function and services in the study area, urgent actions are therefore warranted.

The findings of this work are generally aligned with observations across various settings of the world that the impact of refugees on the local environment can be staggering (Hagenlocher et al. 2012; Ndyeshumba, 2000), though primary outcome can be widespread deforestation (Black, 1994). Loss of natural resources is expected to continue in the coming years since repatriation is in halt despite many attempts of the host country, Bangladesh. Since the study area is very prone to landslide, further disappearance of forest cover would not only detrimental to environmental degradation but can lead to frequent slope failures, which may put both Rohingya and local communities at extreme risk of landslide hazards (Ahmed et al. 2020). As Rohingya populations (currently 932,940) in the study area outnumbered local population of 471,768 (BBS, 2011), various issues, besides environmental degradation, are often reported including social conflict between the two competing groups. We assert that the findings of this work can contribute significantly to devise strategies for conserving and managing forest ecosystem of an ecologically critical area. Hence, government of Bangladesh (GoB) and development partners can prioritize ecosystem management to promote ecological sustainability in the study area.

\section{Conclusion}

In the process of evaluating the impact of Rohingya influx to forest ecosystem function in Cox's Bazar- Teknaf peninsula, this study considered multiple factors to showcase present and future land use/cover change as well as loss of ecosystem function in an ecologically sensitive area. Multitemporal Sentinel imagery and collateral data were employed to quantify changes in forest cover and predict their distribution by incorporating important dynamic variables into the model. The results showed that forest cover degraded substantially to accommodate a large number of refugees that led to deterioration of forest ecosystem functions. Significant amount of above ground biomass loss and release of tons of carbons to the atmosphere in response to refugee rehabilitation were noteworthy. Importantly, this study quantified that 27,600 tons of carbon may have released to the atmosphere between 2017 and 2019 because of widespread deforestation. Further, modelling exercise indicated that the extent of forested lands and associated ecosystem functions could degrade substantially than might have anticipated at present. Consequently, wildlife habitat associated with forest degradation and fragmentation could endanger a number of flora and fauna, including the Asian elephant.

Despite this study has many implications (e.g. conservation of forest, policies), lack of cloud free satellite data was a major constraint to depict forest cover changes over different seasons. Hence, future work could use microwave data during the monsoon season and determine how regeneration of shrubs and mixed forest is occurring in the area. Taking regeneration of trees and shrubs into account may be useful to predict future changes of ecosystem functions. In addition, growth rate of Rohingya population was not considered in this study, accounting their growth rate could be of value to include in the dynamic model, used in this 
work. Finally, use of secondary data to estimate AGB may have under/over- estimated actual figures. Even though deriving biomass data from the field is time and labor- intensive, an ongoing work could provide better estimate related to biomass loss and carbon release, as a result of forest clearance, caused by Rohingya refugees. Despite these limitations, this work can be highly useful to determine the impact of refugee crisis on the environment with geospatial data in Bangladesh and elsewhere.

\section{Conflict of Interest}

The manuscript has been approved by all authors and has never been published, or under consideration at present for publication elsewhere. The authors confirm that there is no conflict of interest in publishing this research article by Land Degradation and Development journal.

\section{References}

1. Abdullah, A.Y.M., Masrur, A., Adnan, M.S.G., Baky, M.A.A., Hassan, Q.K., Dewan, A. (2019). Spatio-Temporal Patterns of Land Use/Land Cover Change in the Heterogeneous Coastal Region of Bangladesh between 1990 and 2017. Remote Sens, 11(7) , 790. doi:org/10.3390/rs11070790

2. Ahmed, B., Rahman, M. S., Sammonds, P., Islam, R., Uddin, K. (2020). Application of geospatial technologies in developing a dynamic landslide early warning system in a humanitarian context: the Rohingya refugee crisis in Cox's Bazar, Bangladesh. Geomatics, Natural Hazards and Risk, 11( 1), 446-468. doi: 10.1080/19475705.2020.1730988

3. Ahmed, N., Islam, M. N., Hasan, M. F., Motahar, T., \& Sujauddin, M. (2019). Understanding the political ecology of forced migration and deforestation through a multi-algorithm classification approach: the case of Rohingya displacement in the southeastern border region of Bangladesh. Geology, Ecology, and Landscapes, 3(4), 282-294.doi:10.1080/24749508.2018.1558025

4. Alam MF., Uddin MZ., Hasan MA. (2012) Evaluation of plant biodiversity in Teknaf wildlife sanctuary, Bangladesh. LAP LAMBERT Academic Publishing, Saarbrücken

5. Alam, S., Misbahuzzaman, K., Rahman, M., \& Kabir, M. (2015). Threats to the Teknaf Wildlife Sanctuary of Bangladesh. Journal of Environmental Science and Natural Resources, 7(1).doi:10.3329/jesnr.v7i1.22176

6. Anderson, R., Hardy, E. E., Roach, J. T., \& Witmer, R. E. (1976). A land use and land cover classification system for use with remote sensor data. USGS Professional Paper 964 . Washington, DC. doi.org/10.3133/pp964

7. Babu, S. C., \& Hassan, R. (1995). International migration and environmental degradation - the case of Mozambican refugees and forest resources in Malawi. Journal of Environmental Management , 43 (3), 233-247. doi:10.1016/s0301-4797(95)90414-x

8. Bangladesh Forest Department. GIS database of the Beat, Ranges, and Forest Divisions of Bangladesh Forest Areas, RIMS Unit, Agargaon, Dhaka, Bangladesh

9. Bashar, I. (2018). Impact of the Rohingya crisis on the threat landscape of the Myanmar-Bangladesh border. Combatting violent extremism and terrorism in Asia and Europe: From cooperation to collaboration, 29-42.

10. Bauer, M. E., Burk, T. E., Ek, A. R., Coppin, P. R., Lime, S. D., Walters, D. K., et al. (1994). Satellite inventory of Minnesota forests. Photogrammetric Engineering and Remote Sensing ,60(3), 287- 298.

11. BBS. (2011). Population and housing census 2011. Bangladesh Bureau of Statistics (BBS), Ministry of Planning, Government of the People's Republic of Bangladesh, Dhaka,

12. Belal, M.A.H. (2013). Effectiveness of co-management committees in Teknaf Wildlife Sanctuary. Connecting Communities and Conservaion: Co-management Initiative Implemented by IPAC in Wetlands and Forests of Bangladesh. USAID, Bangladesh.

13. BFD (2014). Wildlife sanctuary: protected areas of Bangladesh. Bangladesh Forest Department. [PDF file, Updated 2011 Dec 15; cited 2014 December 03]. Retrieved from: http://www.bforest.gov.bd/ index.php/protected-areas

14. Butler, Rhett A.(2012). Rainforest Diversity: Role of climate in rainforest biodiversity. Mongabay.com. Retrieved from https://rainforests.mongabay.com/0302.htm. (Retrieved on 01 May 2020) 
15. Byron, N., Arnold, M. (1999). What features for the people of the tropical forest? World Dev 27(5) :789-805. doi:org/10.1016/S0305-750X(99)00025-X

16. Bjorgo, E. (2000). Refugee Camp Mapping Using Very High Spatial Resolution Satellite Sensor Images. Geocarto International , 15(2), 79-88. doi:10.1080/10106049908542156

17. Bjørgo, E. (1999). Very high-resolution satellites: A new source of information in humanitarian relief operations. Bull. Am. Soc. Inf. Sci. 1999, 26, 22-24. Doi: 10.1002/bult.138

18. Bolstad, P. V., \& Lillesand, T. D. (1991). Rapid Maximum Likelihood classification. Photogrammetric Engineering \& Remote Sensing, 57, 67-74

19. Bonan, G. B. (2008). Forests and climate change: forcings, feedbacks, and the climate benefits of forests. science, 320(5882), 1444-1449. doi:10.1126/science.1155121

20. Bouchardy, J.-Y. (1995). Development of a GIS System in UNHCR for Environmental, Emergency, Logistic, and Planning Purposes; Program Report; DPOS UNHCR: Geneva, Switzerland. Available online: http://repository.forcedmigration.org/show_metadata.jsp?pid=fmo:3246 (accessed on 20 March 2013).

21. Black, R. (1994). Forced migration and environmental change: the impact of refugees on host environments. Journal of Environmental Management , 42 (3), 261-277. doi:10.1006/jema.1994.1072

22. Black, R., \& Sessay, M. F. (1998). Refugees and environmental change in West Africa: the role of institutions. Journal of International Development , 10 (6), 699-713. doi:10.1002/(sici)10991328(1998090)10:6<699::aid-jid511>3.0.co;2-z

23. Chambers, R. (1986). Hidden Losers? The Impact of Rural Refugees and Refugee Programs on Poorer Hosts. International Migration Review, Volume: 20 issue: 2, page(s): 245-263. doi:10.1177/019791838602000207

24. Chen, X., \& Li, B.-L. (2003). Change in soil carbon and nutrient storage after human disturbance of a primary Korean pine forest in Northeast China. Forest Ecology and Management, 186(1-3), 197206. doi:10.1016/s0378-1127(03)00258-5

25. Clevers, J.G.; Kooistra, L.; van den Brande, M.M. (2017). Using Sentinel-2 data for retrieving LAI and leaf and canopy chlorophyll content of a potato crop. Remote Sens. 2017, 9, 405. doi:10.3390/rs9050405

26. Department of Environment. (2015). Community Based Ecosystem Conservation and Adaptation in Ecologically Critical Areas of Bangladesh: Responding to Nature and Changing Climate. Department of Environment (DoE), Ministry of Environment and Forests, Dhaka, Bangladesh, pp x+122.

27. Foley, J.A., Asner, G.P., Costa, M.H., Coe, M.T., DeFries, R., Gibbs, H.K., Howard, E.A., Olson, S., Patz, J., Ramankutty, N., Snyder, P. (2007). Amazonia revealed: forest degradation and loss of ecosystem goods and services in the Amazon Basin, The Ecological Society of America. doi:org/10.1890/1540-9295(2007)5[25:ARFDAL]2.0.CO;2

28. Ghimere, K. (1996). Refugees and deforestation. In: Birendra KC, Shin N (eds) Refugee impact on collective management of forest resources: a case study of Bhutanese refugees in Nepal's Eastern Terai region.J For Res $11: 305-311$.

29. Government of Bangladesh (GoB). (2009). Government of Bangladesh Gazette notification no. pabama/parisha-4/nishorgo/105/sting/2006/398dt.23/11/2009.

30. Green, MJB. (1987). World conservation monitoring centre, IUCN commission on natural parks and protected areas. Teknaf game reserve, IUCN Directory of South Asian Protected Areas, pp 38-43.

31. GTZ (Gesellschaft filr Technische Zusamnrenarbeit) (1994). RESCUE, First Year Report, April 1993Aprfl 1994. GTZ, Federal Republic of Germany.

32. Hagenlocher, M., Lang, S., \& Tiede, D. (2012). Integrated assessment of the environmental impact of an IDP camp in Sudan based on very high resolution multi-temporal satellite imagery. Remote Sensing of Environment, 126 , 27-38. doi:10.1016/j.rse.2012.08.010

33. Halmy, M. W. A., Gessler, P. E., Hicke, J. A., \& Salem, B. B. (2015). Land use/land cover change detection and prediction in the north-western coastal desert of Egypt using Markov-CA. Applied Geography , 63 , 101-112. doi:10.1016/j.apgeog.2015.06.015

34. Harris, P. M., \& Ventura, S. J. (1995). The integration of geographic data with remotely sensed imagery to improve classification in an urban area. Photogrammetric Engineering 8 Remote Sensing ,61(8), 
993-998.

35. Hassan, M., Smith, A., Walker, K., Rahman, M., \& Southworth, J. (2018). Rohingya Refugee Crisis and Forest Cover Change in Teknaf, Bangladesh. Remote Sensing, 10(5),689. doi:10.3390/rs10050689

36. Hugo, G. (1996). Environmental concerns and international migration. International migration review , 30 (1), 105-131. doi:10.2307/2547462

37. Human Rights Watch (HRW). (2000). Burmese Refugees in Bangladesh: Still No Durable Solution, Vol 12. , No. 3 (C). https://www.hrw.org/reports/2000/burma/index.htm

38. International Organization for Migration (IOM) (2017). NPM 6 Report [pdf file] Retrieved from https://www.iom.int/sites/default/files/country/docs/bangladesh/NPM-Round6-ReportOct2017.pdf. (Retrieved on January 24, 2018)

39. IOM \& FAO (2017). Assessment of fuel wood supply and demand in displacement settings and surrounding areas in Cox's Bazaar District, Dhaka, Bangladesh.

40. United Nations High Commissioner for Refugees (UNHCR) and IUCN Bangladesh (2018). Survey report on elephant movement, human-elephant conflict situation, and possible intervention sites in and around Kutupalong Camp, Cox's Bazaar : survey reporting period : 21 January to 13 February 2018, Bangladesh, IUCN-2018-028, En

41. Kc, B., \& Nagata, S. (2006). Refugee impact on collective management of forest resources: a case study of Bhutanese refugees in Nepal's Eastern Terai region. Journal of Forest Research , 11 (5), 305-311. doi:10.1007/s10310-006-0231-x

42. K.McVeigh, D.Peri. (2018). "fatal elephant attacks on Rohingya Refugees push Bangladesh to act, " The Guardian; Retrieved from https://www.theguardian.com/global-development/2018/may/09/fatalelephant-attacks-on-rohingya-refugees-push-bangladesh-to-act

43. Khan, A. (2015). Elephas maximus. In: IUCN Bangladesh. Red List of Bangladesh, Volume 2 : Mammals. IUCN, International Union for Conservation of Nature, Bangladesh Country Office, Dhaka, Bangladesh. p 65.

44. Khan, MMH. (2008). Protected areas of Bangladesh- a guide to wildlife. Nisorgo program, Bangladesh Forest Department, Dhaka, Bangladesh.

45. Kolstad, K. (2018, August 24). Cox's Bazar: The world's largest refugee settlement, Norwegian Refugee Council (NRC). Retrieved from https://www.nrc.no/news/2018/august/coxs-bazar-the-worlds-largestrefugee-settlement/. Retrieved 23 September 2019.

46. Li, Y., Li, M., Li, C. et al. Forest aboveground biomass estimation using Landsat 8 and Sentinel-1A data with machine learning algorithms. Sci Rep 10, 9952 (2020). https://doi.org/10.1038/s41598020-67024-3

47. Lodhi, M. A., Echavarria, F. R., \& Keithley, C. (1998). Using remote sensing data to monitor land cover changes near Afghan refugee camps in northern Pakistan. Geocarto International , 13 (1), 33-39. doi:10.1080/10106049809354626

48. Lynch, M. (2002). Reducing Environmental Damage Caused by the Collection of Cooking Fuel by Refugees." Refugee, Vol. 21 , Issue 1. Retrieved from http://www.yorku.ca/crs/Refuge/refuge_-_volume_21,_issue_no__1.htm (Retrieved on January 24, 2018). doi.org/10.25071/1920-7336.21280

49. Malhi, Y., Meir, P., \& Brown, S. (2002). Forests, carbon and global climate. Philosophical Transactions of the Royal Society of London. Series A: Mathematical, Physical and Engineering Sciences, 360(1797), 1567-1591. doi: 10.1098/rsta.2002.1020

50. Morales-Hidalgo, D., Oswalt, S. N., \& Somanathan, E. (2015). Status and trends in global primary forest, protected areas, and areas designated for conservation of biodiversity from the Global Forest Resources Assessment 2015. Forest Ecology and Management, 352, 68-77. doi:10.1016/j.foreco.2015.06.011

51. Moslehuddin, A.Z.M.; Rahman, M.A.; Ullah, S.M.A.; Moriyama, M.; Tani, M. (2018). Physiography, Forests, and People in Teknaf. In Deforestation in the Teknaf Peninsula of Bangladesh; Tani, M., Rahman, M., Eds.; Springer:Singapore. doi: 10.1007/978-981-10-5475-4

52. Motaleb, M.A., Ahmed, M.S. (2016). Status of Asian Elephants in Bangladesh. IUCN-International Union for Conservation of Nature, Dhaka. 
53. National Geographic (2018) Retrieved from https://www.nationalgeographic.com/animals/2018/11/rohingyarefugee-crisis-elephants-bangladesh/ (Accessed on 25 September 2019)

54. Nishorgo (2019). Retrived from http://nishorgo.org/project/inani-rf/ [Last accessed on 18 February 2018]

55. Ndyeshumba, P. (2000). The use of remote sensing for environmental impact assessment and determination of the area affected by refugees in Ngara Districts North Western Tanzania. International Archives of Photogrammetry and Remote Sensing. Vol. XXXIII , Part B7.

56. Panja, P. (2020). Is the forest biomass a key regulator of global warming? A mathematical modelling study. Geology, Ecology, and Landscapes , 1-9. doi: 10.1080/24749508.2020.1752021

57. Pijanowski, B., Brown, D., Shellito, B., \& Manik, G. (2002). Using neural networks and GIS to forecast land use changes: a land transformation model. Computers, Environment and Urban Systems ,26 , $553 \mathrm{e} 575$.

58. Pontius, R. G., \& Millones, M. (2011). Death to Kappa: birth of quantity disagreement and allocation disagreement for accuracy assessment. International Journal of Remote Sensing, 32, 4407-4429. doi:10.1080/01431161.2011.552923

59. Quintano, C.; Fernández-Manso, A.; Fernández-Manso, O. (2018). Combination of Landsat and Sentinel-2 MSI data for initial assessing of burn severity. Int. J. Appl. Earth Obs. Geoinf, 64, 221225. doi:10.1016/j.jag.2017.09.014

60. Rahman, A. (2011). Integrated protected Area Co-Management in TWS, USAID

61. Rahman, M. Z. (2017). Livelihoods of Rohingyas and Their Impacts on Deforestation. Deforestation in the Teknaf Peninsula of Bangladesh, 113-125. doi:10.1007/978-981-10-5475-4_9

62. Rahman, U. (2010). The Rohingya Refugee: A Security Dilemma for Bangladesh. Journal of Immigrant \& Refugee Studies. Volume 8, 2010 - Issue 2. doi: 10.1080/15562941003792135

63. Rashid, K. J., Hoque, M. A., Esha, T. A., Rahman, M. A., \& Paul, A. (2020). Spatiotemporal changes of vegetation and land surface temperature in the refugee camps and its surrounding areas of Bangladesh after the Rohingya influx from Myanmar. Environment, Development and Sustainability. doi:10.1007/s10668-020-00733-x

64. Romijn, E., Lantican, C. B., Herold, M., Lindquist, E., Ochieng, R., Wijaya, A., .. Verchot, L. (2015). Assessing change in national forest monitoring capacities of 99 tropical countries. Forest Ecology and Management, 352, 109-123. doi:10.1016/j.foreco.2015.06.003

65. Sato, H., Yasui, K., \& Byamana, K. (2000). Follow-up survey of environmental impacts of the Rwandan refugees on eastern D. R. Congo.Ambio, 29, 122-123.

66. Tani M. and Rahman, Md. A. 2018 (Eds.) "Deforestation in the Teknaf Peninsula of Bangladesh - A Study of Political Ecology". Springer International Publishing AG. doi: https://doi.org/10.1007/978981-10-5475-4

67. UNDP Bangladesh and UN WOMEN Bangladesh (2018). Report on Environmental Impact of Rohingya Influx. Dhaka, Bangladesh, p 106 (including cover)

68. Shukla, J. B., Lata, K., \& Misra, A. K. (2011). Modeling the depletion of a renewable resource by population and industrialization: Effect of technology on its conservation. Natural Resource Modeling , 24 (2), 242-267.

69. Siry, J.P., Cubbage, F.W., Ahmed, M.R. (2003). Sustainable Forest Management: Global Trends and Opportunities, XII World Forestry Congress, Québec City, Canada 21-28 September 2003. doi:10.1016/j.forpol.2003.09.003

70. UNHCR. (2019). GLOBAL TRENDS: FORCED DISPLACEMENT IN 2018. 2019 United Nations High Commissioner for Refugees. 1211 Geneva, Switzerland.

71. UNHCR (2017). Statelessness and the Rohingya Crisis [PDF file]. Retrieved from https://www.refworld.org/pdfid/5a05b4664.pdf

72. UNOCHA. Rohingya refugee crisis. Retrieved from https://www.unocha.org/rohingyarefugee-crisis (accessed on Jan 8, 2018).

73. Wang, K., Ye, H., Chen, F., Xiong, Y., \& Wang, C. (2012). Urbanization Effect on the Diurnal Temperature Range: Different Roles under Solar Dimming and Brightening*. Journal of Climate, 25(3), 
1022-1027. doi:10.1175/jcli-d-10-05030.1

74. WILSON, K. B. (1994). Internally Displaced, Refugees and Returnees from and in Mozambique. Studies on Emergencies and Disaster Relief, No. 1 . Nordiska Afrikatnstitutet, Reprocentralen HSC.

75. Yuan, F., Sawaya, K. E., Loeffelholz, B. C., \& Bauer, M. E. (2005). Land cover classification and change analysis of the Twin Cities (Minnesota) Metropolitan Area by multitemporal Landsat remote sensing. Remote Sensing of Environment, 98(2-3),317-328. doi:10.1016/j.rse.2005.08.006

76. Zhang, H., Qi, Z., Ye, X., Cai, Y., Ma, W., \& Chen, M. (2013). Analysis of land use/land cover change, population shift, and their effects on spatiotemporal patterns of urban heat islands in metropolitan Shanghai, China. Applied Geography, 44 , 121-133. doi:10.1016/j.apgeog.2013.07.021

77. Zolkos, S.G., Goetz, S.J., Dubayah, R. (2013). A meta-analysis of terrestrial aboveground biomass estimation using lidar remote sensing. Remote Sensing of Environment. 128, 289-298. doi:10.1016/j.rse.2012.10.017

Table 1 Types of data used in this study

\begin{tabular}{llll}
\hline Data type & Year & Spatial resolution & Source \\
\hline Sentinel 2A & $2019-02-13$ & $10 \mathrm{~m}$ & https://scihub.copernicus.eu/dhus/\#/home \\
& $2018-02-18$ & & \\
& $2017-02-18$ & & \\
RapidEye & $2015-2016$ & $5 \mathrm{~m}$ & Bangladesh Forest Department (BFD) \\
World View-2 & $2011-2013$ & $2 \mathrm{~m}$ & USAID \\
Google Earth images & $2017-2019$ & $<2 \mathrm{~m}$ & Google Earth Pro \\
Unmanned aerial vehicle (UAV) images & $2017-2019$ & $10 \mathrm{~cm}$ & United Nations High Commissioner for Refu \\
SRTM & 2000 & $30 \mathrm{~m}$ & United States of Geological Survey (USGS) \\
National administration boundary & $\mathrm{N} / \mathrm{A}$ & $\mathrm{NA}$ & Survey of Bangladesh (SOB) \\
Forest administration boundary & 2015 & $\mathrm{NA}$ & Bangladesh Forest Department (BFD) \\
Refugee camps & 2019 & $\mathrm{NA}$ & United Nations High Commissioner for Refu \\
Human trails & $2017-2019$ & $<30 \mathrm{~cm},<2 \mathrm{~m}$ & UAV image, Google Earth \\
\hline
\end{tabular}

Table 2 Land use and land cover classification scheme

\begin{tabular}{ll}
\hline LULC types & Descriptions \\
\hline Agriculture (AC) & Perennial/seasonal agricultural activities \\
Saltpan (SP) & Salt production, drivers of forest degradation \\
Urban (UB) & Anthropogenic disturbances \\
Homestead vegetation (HS) & includes household vegetation and the houses underneath \\
Brick kiln (BK) & Anthropogenic stressors, drivers of degradation \\
Shrubs (SH) & Non-timber forest, low heights, grasses, and creeping vegetations \\
Mixed forest (MF) & Non-timber forest, mixed height forest with sparse tree canopies \\
Plantation forest (PT) & Young seedling and sapling, anthropogenic stimulus for forest health, reforestation \\
Canopy forest (CF) & Timber forest and healthy vegetation \\
Casuarina (CR) & Coastal vegetation with canopy coverage \\
Rohingya camps (CA) & A complete transformation of forest cover to other class \\
Degraded forest (DF) & Poor vegetation health \\
Creeks (CK) & small canals and streams \\
Waterbodies (WB) & Lake, ponds, rivers \\
\hline
\end{tabular}

Table 3 Suitable factors for forest degradation 


\begin{tabular}{|c|c|c|c|}
\hline Factors & Influencing LULC class(s) & Influence type & weight \\
\hline \multirow[t]{6}{*}{ Rohingya Population } & Degraded forest & Stimulus & Very High \\
\hline & Shrubs & Stressor & Very High \\
\hline & Mixed forest & Stressor & Very High \\
\hline & Canopy forest & Stressor & High \\
\hline & Plantation forest & Stressor & High \\
\hline & Rohingya camps & Stimulus & High \\
\hline \multirow[t]{6}{*}{ Distance from roads } & Degraded forest & Stimulus & Medium \\
\hline & Shrubs & Stressor & Medium \\
\hline & Mixed forest & Stressor & Medium \\
\hline & Canopy forest & Stressor & Medium \\
\hline & Plantation forest & Stressor & Low \\
\hline & Rohingya camps & Stimulus & High \\
\hline \multirow[t]{6}{*}{ Distance from human trails } & Degraded forest & Stimulus & High \\
\hline & Shrubs & Stressor & Low \\
\hline & Mixed forest & Stressor & Medium \\
\hline & Canopy forest & Stressor & Medium \\
\hline & Plantation forest & Stressor & Low \\
\hline & Rohingya camps & Stimulus & Medium \\
\hline \multirow[t]{5}{*}{ Distance from camp } & Degraded forest & Stimulus & High \\
\hline & Shrubs & Stressor & High \\
\hline & Mixed forest & Stressor & High \\
\hline & Canopy forest & Stressor & High \\
\hline & Plantation forest & Stressor & High \\
\hline \multirow[t]{5}{*}{ Elevation } & Degraded forest & Stressor & Medium \\
\hline & Shrubs & Stimulus & High \\
\hline & Mixed forest & Stimulus & High \\
\hline & Canopy forest & Stimulus & High \\
\hline & Plantation & Stimulus & Low \\
\hline \multirow[t]{5}{*}{ Distance from degraded forest } & Degraded forest & Stimulus & High \\
\hline & Shrubs & Stressor & High \\
\hline & Mixed forest & Stressor & High \\
\hline & Canopy forest & Stressor & High \\
\hline & Plantation forest & Stressor & High \\
\hline
\end{tabular}

Table 4 Area statistics of LULC in the study area, 2017-2019

\begin{tabular}{lllllll}
\hline LULC types & $\mathbf{2 0 1 7}$ & \multicolumn{3}{c}{$\mathbf{2 0 1 8}$} & \multicolumn{3}{c}{$\mathbf{2 0 1 9}$} \\
\hline & Area (ha) & $\%$ & Area (ha) & $\%$ & Area (ha) & $\%$ \\
Agriculture & 9894.89 & 24.04 & 9627.35 & 23.39 & 9437.29 & 22.93 \\
Saltpan & 309.88 & 0.75 & 309.67 & 0.75 & 309.6 & 0.75 \\
Urban area & 49.62 & 0.12 & 41.39 & 0.10 & 41.41 & 0.10 \\
Homestead vegetation & 6013.54 & 14.61 & 5886.9 & 14.30 & 5804.79 & 14.10 \\
Brick kilns & 35.77 & 0.09 & 35.77 & 0.09 & 35.77 & 0.09 \\
Shrubs & 8801.55 & 21.38 & 8195.01 & 19.91 & 7306.34 & 17.75 \\
Mixed forest & 10593.09 & 25.73 & 9645.3 & 23.43 & 9303.84 & 22.60 \\
Plantation forest & 1210.04 & 2.94 & 1097.12 & 2.67 & 1049.58 & 2.55 \\
Canopy forest & 1463.85 & 3.56 & 1355.15 & 3.29 & 1278.99 & 3.11 \\
Casurina & 28.77 & 0.07 & 28.75 & 0.07 & 28.75 & 0.07 \\
Rohingya camps & 78.39 & 0.19 & 1261.95 & 3.07 & 1968.05 & 4.78
\end{tabular}




\begin{tabular}{lllllll}
\hline LULC types & $\mathbf{2 0 1 7}$ & & $\mathbf{2 0 1 8}$ & & $\mathbf{2 0 1 9}$ & \\
\hline Degraded forest & 1862.69 & 4.53 & 2866.3 & 6.96 & 3792.02 & 9.21 \\
Creeks & 507.32 & 1.23 & 501.27 & 1.22 & 496.42 & 1.21 \\
Waterbodies & 312.99 & 0.76 & 310.46 & 0.75 & 309.54 & 0.75 \\
Total & $\mathbf{4 1 1 6 2 . 4}$ & & $\mathbf{4 1 1 6 2 . 4}$ & & $\mathbf{4 1 1 6 2 . 4}$ & \\
\hline
\end{tabular}

Table 5 Conversion of forest covers to refugee camps and degraded vegetation, 2017- 2019 (area in ha)

\begin{tabular}{llll}
\hline 'From class' & 'To class' & $\mathbf{2 0 1 7 - 2 0 1 8}$ & $\mathbf{2 0 1 8 - 2 0 1 9}$ \\
\hline Agriculture & Camps & 282.04 & 198.03 \\
Homestead vegetation & Camps & 130.42 & 85.35 \\
Shrubs & Camps & 302.41 & 54.17 \\
\multirow{2}{*}{ Mixed forest } & Degraded forest & 398.59 & 851.17 \\
& Camps & 281.00 & 12.22 \\
Planted trees & Degraded forest & 562.06 & 314.77 \\
& Camps & 45.47 & 1.40 \\
Canopy forest & Degraded forest & 58.82 & 46.14 \\
& Camps & 76.18 & 3.98 \\
& Degraded forest & 40.13 & 72.09 \\
\hline
\end{tabular}

Table 6 Correlation matrix, showing strengths of the relationship among six LULC categories and population

\begin{tabular}{llllllll}
\hline & Population & CF & MF & SH & PT & DF & CA \\
\hline Population & 1 & & & & & & \\
CF & -0.93669 & 1 & & & & & \\
MF & -0.98126 & 0.986606 & 1 & & & & \\
SH & -0.84323 & 0.978074 & 0.931003 & 1 & & & \\
PT & -0.97413 & 0.991593 & 0.999419 & 0.942903 & 1 & & \\
DF & 0.906571 & -0.99696 & -0.9709 & -0.99132 & -0.9785 & 1 & \\
CA & 0.951057 & -0.99905 & -0.99278 & -0.96807 & -0.99629 & 0.992622 & 1 \\
\hline
\end{tabular}

CF: canopy forest; MF: mixed forest; SH: shrubs; PT: plantation forest; DF: degraded forest; CA: camps Table 7 Area statistics of predicted LULC for 2023 and 2027

\begin{tabular}{lllll}
\hline LULC types & $\mathbf{2 0 2 3}$ & $\mathbf{2 0 2 7}$ & Area change (2019-2023) & Area change (2019-2027) \\
\hline Agriculture & 9450.82 & 9465.92 & 13.53 & -28.63 \\
Saltpan & 309.5 & 309.44 & -0.1 & -0.16 \\
Urban & 41.41 & 41.41 & 0.0 & 0.0 \\
Homestead vegetation & 5804.41 & 5803.26 & -0.38 & -1.53 \\
Brick kiln & 35.77 & 35.77 & 0.0 & 0.0 \\
Shrubs & 5800.1 & 4871.53 & -1506.24 & -2434.81 \\
Mixed forest & 8039.04 & 7144.4 & -1264.8 & -2159.4 \\
Planted young forest & 911.48 & 816.62 & -138.1 & -232.96 \\
Canopy forest & 1109.63 & 990.62 & -169.36 & -288.37 \\
Casurina patches & 28.75 & 28.75 & 0.0 & 0.0 \\
Rohingya camps & 1968.98 & 1972.05 & 0.93 & 4.0
\end{tabular}




\begin{tabular}{lllll}
\hline LULC types & $\mathbf{2 0 2 3}$ & $\mathbf{2 0 2 7}$ & Area change (2019-2023) & Area change (2019-2027) \\
\hline Degraded forest & 6872.12 & 8911.04 & 3080.1 & 5119.02 \\
Creeks and streams & 482.24 & 464.85 & -14.18 & -31.57 \\
Waterbodies & 308.14 & 306.73 & -1.4 & -2.81 \\
\hline
\end{tabular}

Area in ha, '-' denotes loss and ' + ' represents increase

Table 8 Predicted degradation of major forest covers in 2023 and 2027 (area in ha)

\begin{tabular}{lllll}
\hline LULC types & $\mathbf{2 0 2 3}$ & $\mathbf{2 0 2 3}$ & $\mathbf{2 0 2 7}$ & $\mathbf{2 0 2 7}$ \\
\hline & Camps & Degraded forest & Camps & Degraded forest \\
Agriculture & - & - & - & \\
Homestead vegetation & - & - & - & \\
Shrubs & - & 1585.39 & - & 2538.17 \\
Mixed forest & - & 1185.65 & - & 2056.08 \\
Planted trees & - & 127.7 & - & 218.02 \\
Canopy forest & - & 179.76 & - & 303.31 \\
\hline
\end{tabular}

Table 9 Changes in biomass and carbon stocks in Cox's Bazar- Teknaf peninsula, 2017- 2027

\begin{tabular}{lll}
\hline Forest types & Existing and projected loss of biomass and carbon (ton) & Existing and projected loss of biomass and ce \\
& 2017 & 2017 \\
& AGB & Carbon \\
Shrubs & 18 & 9 \\
Mixed forest & 180114 & 90057 \\
Plantation forest & 2 & 1 \\
Canopy forest & 263549 & 131774 \\
Total & $\mathbf{4 4 3 6 8 3}$ & $\mathbf{2 2 1 8 4 1}$ \\
\hline
\end{tabular}




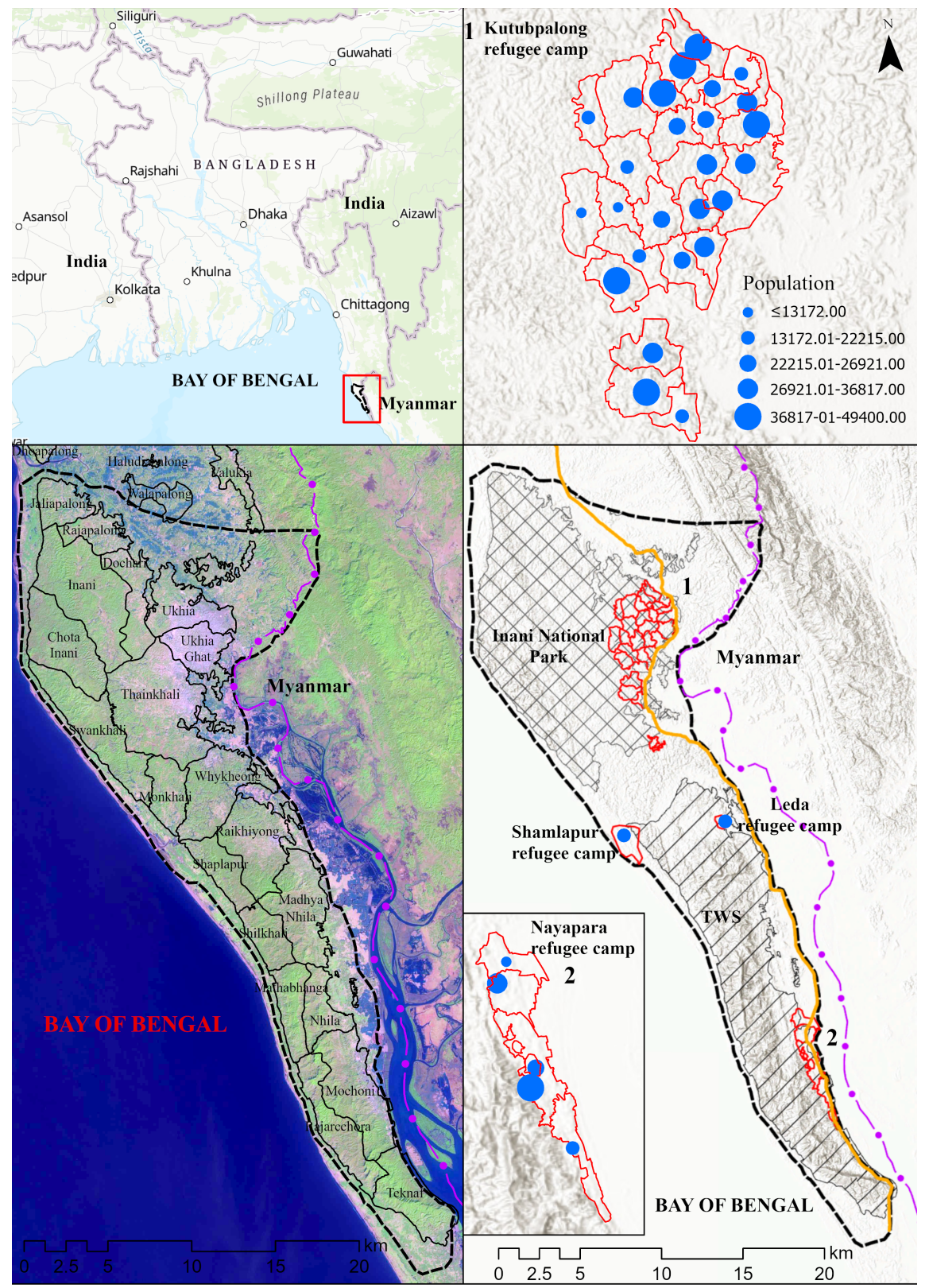



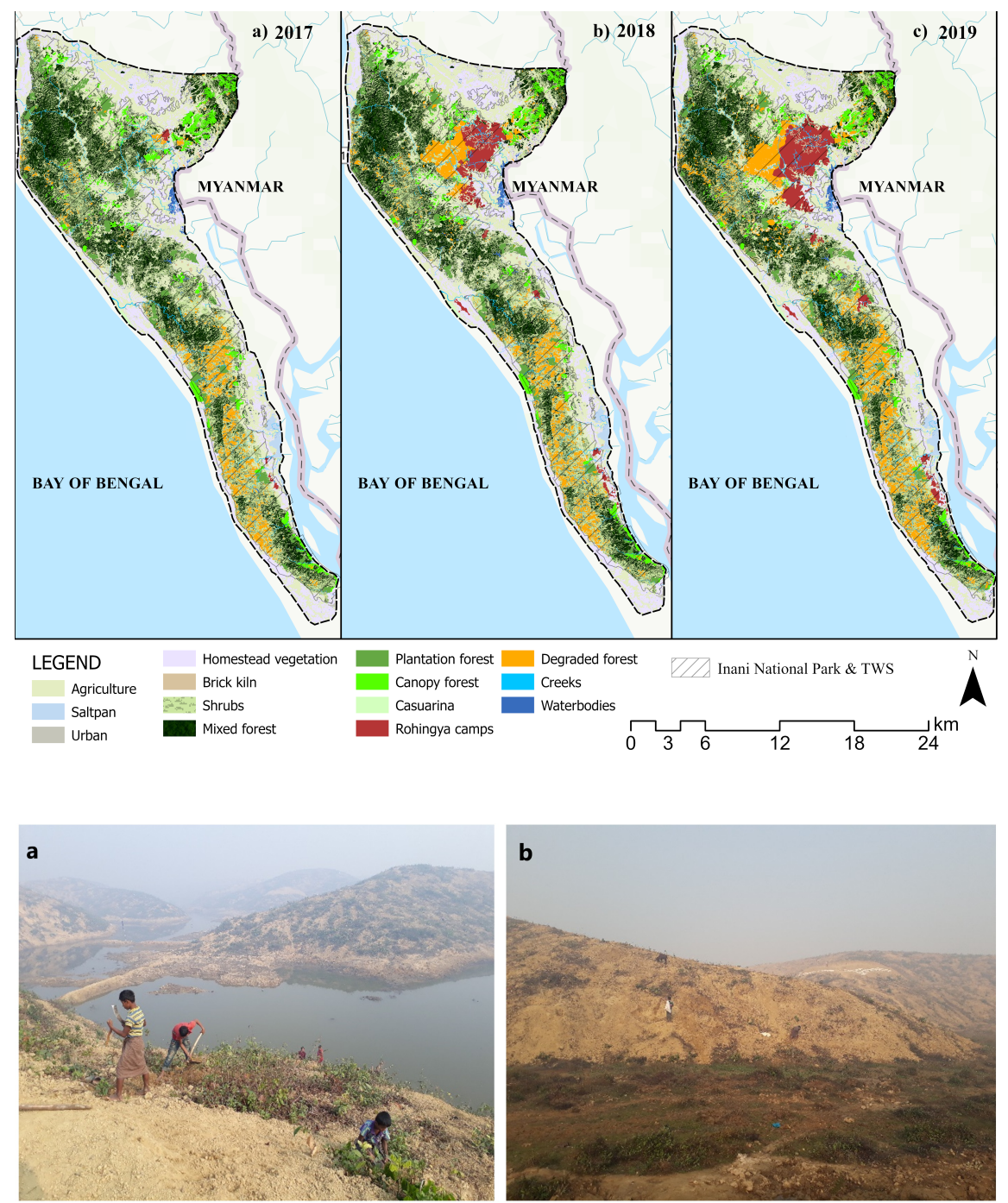

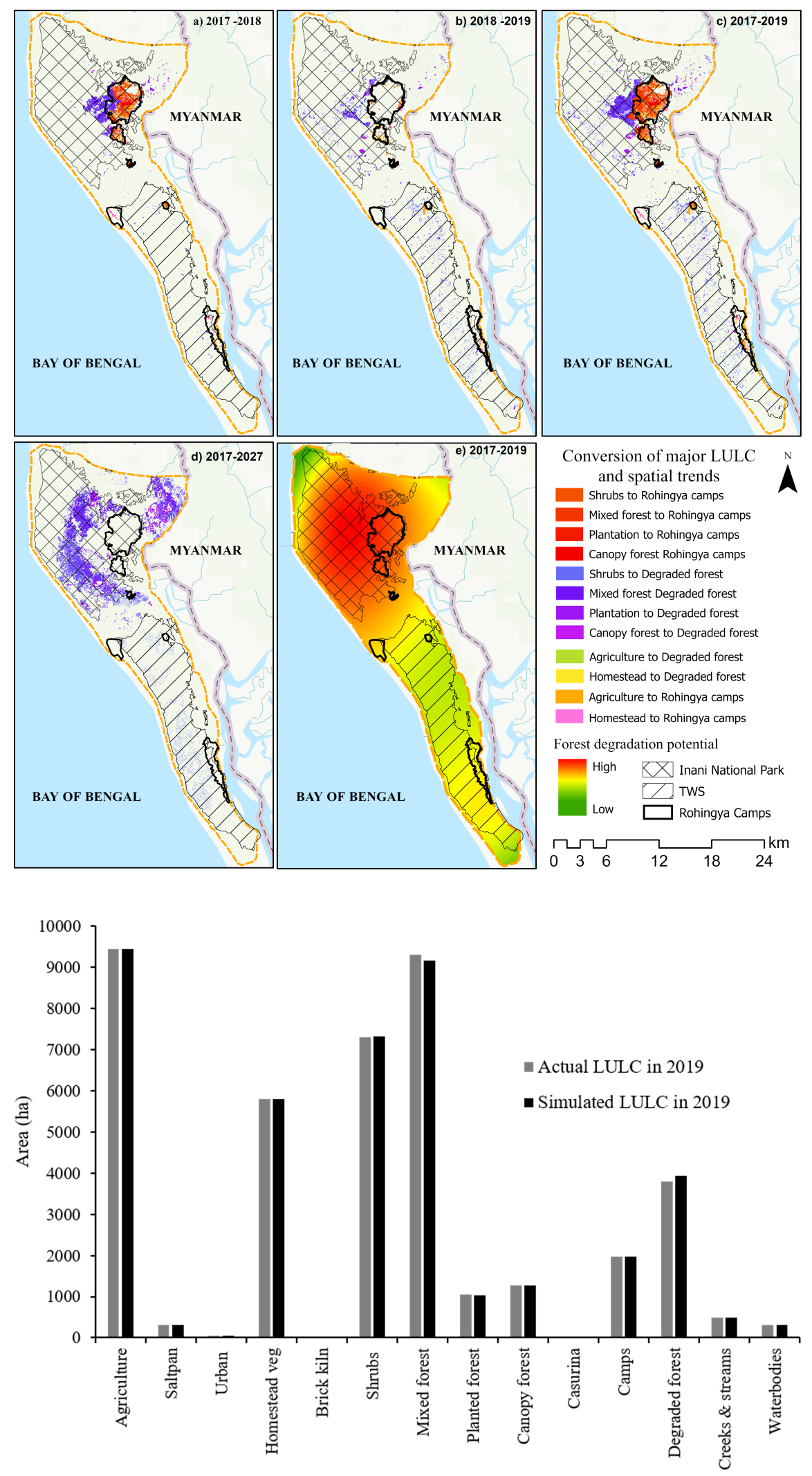


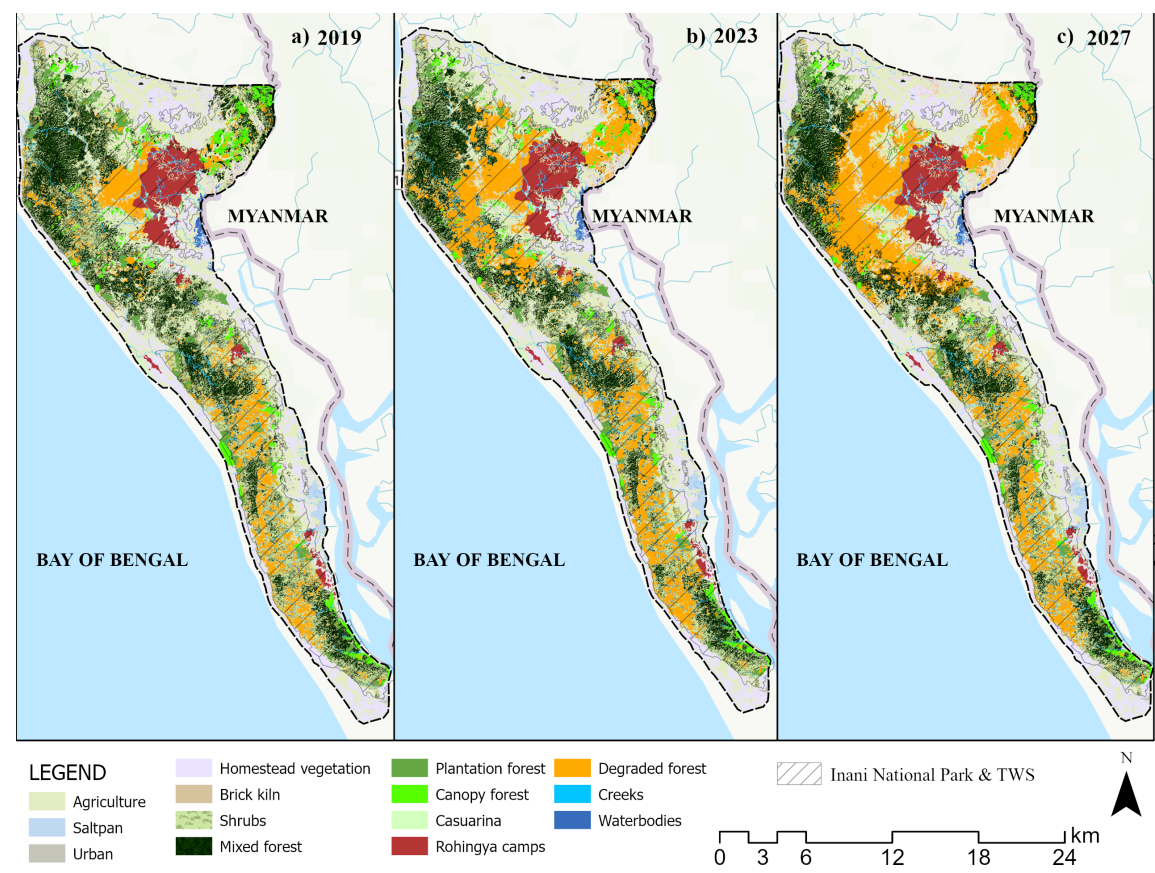




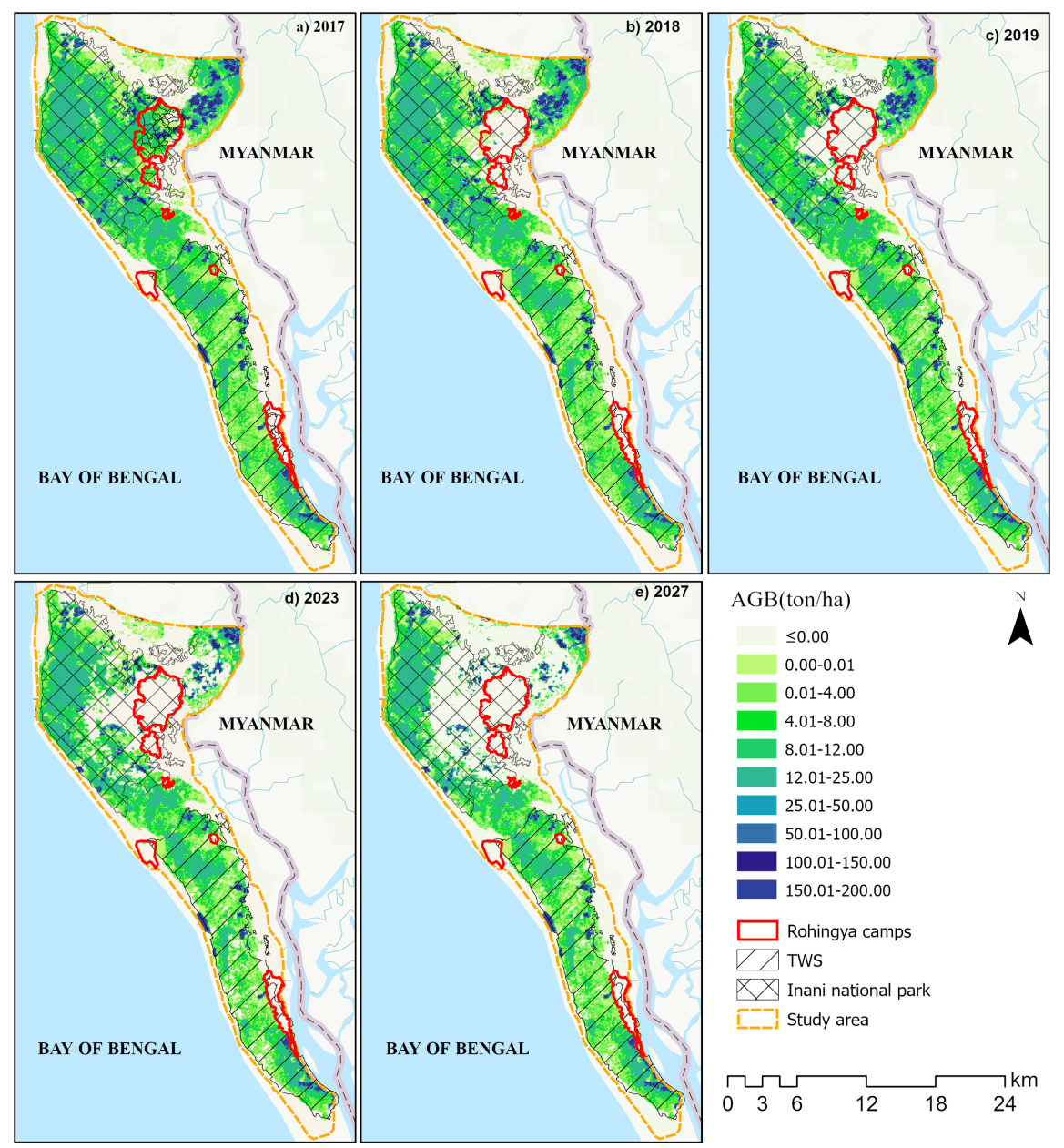

